\title{
PENGEMBANGAN BUKU SUPLEMEN TEKS NEGOSIASI BERMUATAN KEARIFAN LOKAL TIMOR DENGAN PENDEKATAN CONTENT LANGUAGE INTEGRATIVE LEARNING
}

\author{
Maria Rosalinda Talan \\ Universitas Negeri Surabaya \\ Surabaya, Indonesia \\ E-mail: maria_rosalindatalan@yahoo.co.id
}

\begin{abstract}
Abstrak
Berdasarkan observasi awal pembelajaran Bahasa Indonesia menunjukkan hasil yang belum maksimal karena belum mengkonkretkan kehidupan sosial budaya peserta didik dalam kegiatan pembelajaran. Guru hanya menggunakan buku teks yang bersifat global sehingga kurang mewakili masalah yang nyata bagi peserta didik di Timor. Hal tersebut mengakibatkan peserta didik pasif dalam pembelajaran karena tidak ada kesesuaian kehidupan peserta didik dengan materi pelajaran yang terdapat dalam buku tersebut. Dengan demikian, perlu adanya pengembangan buku suplemen teks negosiasi bermuatan kearifan lokal Timor dengan pendekatan Content Language Integrative Learning (CLIL) untuk menutup kesenjangan antara apa yang terjadi dan apa yang diharapkan dalam pembelajaran Bahasa Indonesia di Timor. Tujuan penelitian ini yaitu mendeskripsikan proses pengembangan buku suplemen teks negosiasi bermuatan kearifan lokal Timor dengan pendekatan CLIL dan mendeskripsikan kualitas pengembangan buku suplemen teks negosiasi bermuatan kearifan lokal Timor dengan pendekatan CLIL. Proses pengembangan menggunakan model Four-D yang diadaptasi sesuai kebutuhan menjadi tahap pendefinisisan (define), perancangan (design), dan pengembangan (development). Hasil penelitian dan pengembangan ini menunjukkan kualitas buku suplemen pada aspek kevalidan berkategori sangat layak, aspek kepraktisan buku suplemen berkategori sangat praktis, dan aspek keefektifan buku suplemen berkategori sangat efektif. Dengan demikian, buku suplemen teks negosiasi yang bermuatan kearifan lokal Timor dengan pendekatan CLIL yang dikembangkan ini berkualitas sehingga dapat digunakan sebagai buku pendamping dalam pembelajaran Bahasa Indonesia bagi guru dan peserta didik di Timor.
\end{abstract}

Kata Kunci: pengembangan buku suplemen teks negosiasi, kearifan lokal Timor, CLIL.

\begin{abstract}
Based on preliminary observation Indonesian Language learning showed that the result has not been maximized because it has not concocted the social life of the learners in the learning activities. Teachers only use textbooks is global so that less representative of the real problems for learners in Timor. This results in passive learners in learning because there is no suitability of life of learners with the subject matter contained in the book. Thus, it is necessary to develop a supplementary book negotiation text containing local wisdom of Timor using Content Language Integrative Learning (CLIL) Approachapproach to close the gap between what is happening and what is expected in Indonesian language learning in Timor. The purpose of this study aims to describe 1) the development process of supplementary book negotiation text containing local wisdom of Timor using Content Language Integrative Learning Approach and 2) the quality of the supplementary book negotiation text containing local wisdom using Content Language Integrative Learning Approach. The development process using Four-D model adapted as needed to define, design, and development. The results of this research and development show the quality of supplement book on the validity aspects categorize very feasible, practical aspects of book supplement categorized very practical, and the effectiveness aspects of book supplement categorized very effective. Thus, supplementary book negotiation text containing local wisdom of Timor using Content Language Integrative Learning Approach developed are of high quality so that they can be used as a companion book for the Indonesian language learning of teachers and learners in Timor.
\end{abstract}

Keyword: negotiation text supplement book development, local wisdom of Timor, CLIL. 


\section{PENDAHULUAN}

Dalam kurikulum 2013 pembelajaran bahasa Indonesia memiliki karakteristik tersendiri dibandingkan dengan kurikulum sebelumnya karena menekankan pembelajaran berbasis teks. Pembelajaran bahasa Indonesia berbasis teks dilaksanakan dengan menerapkan bahwa (1) bahasa hendaknya dipandang sebagai teks, bukan semata-mata kumpulan kata atau kebahasaan, (2) penggunaan bahasa merupakan proses pemilihan bentukbentuk kebahasaan untuk mengungkapkan makna, (3) bahasa bersifat fungsional, yaitu penggunaan bahasa yang tidak pernah dapat dilepaskan dari konteks karena dalam bentuk bahasa yang digunakan itu, tercermin ide, sikap, nilai, da idiologi penggunanya, (4) bahasa merupakan sarana pembentukan kemampuan berpikir manusia (Kemendikbud 2014). Teks memiliki dua unsur utama, yaitu format bahasa dan konteks situasi. Konteks situasi meliputi konteks sosial dan konteks budaya masyarakat tutur bahasa yang menjadi tempat teks tersebut diproduksi. Pembelajaran Bahasa Indonesia berbasis teks memiliki tujuan akhir yaitu menjadikan peserta didik memahami serta mampu menggunakan teks sesuai dengan tujuan sosial teks-teks yang dipelajarinya (Mahsun 2014). Dari pengertian ini dapat disimpulkan bahwa tujuan akhir dari pembelajaran teks negosiasi adalah peserta didik memiliki pengetahuan dan terampil mengguankan teks dalam kehidupan sosialnya.

Kemampuan bernegosiasi sangat penting sebagai bekal peserta didik ketika terjun ke dalam masyarakat. Di samping kemampuan bernegosiasi, peserta didik juga diharapkan mampu berperilaku secara santun dalam bernegosiasi maupun dalam proses berkomunikasi lainya. Untuk itu pembelajaran teks negosiasi tidak hanya menekankan aspek pengetahuan dan keterampilan, melainkan peserta didik perlu dibekali dengan keteladanan serta pembiasaan-pembiasaan sikap sosial dan spiritual sebagai bentuk penumbuhan dan pengembangan pendidikan karakter. Salah satu cara yang dapat dilakukan guru dalam mewujudkan pendidikan karakter kepada peserta didik adalah menanamkan nilainilai budaya seperti kearifan lokal dalam pemodelan teks negosiasi.

Kearifan lokal yang ada di pulau Timor, yakni suku Dawan hingga saat ini masih terus dijalani masyarakat. Misalnya, kearifan lokal tentang pengetahuan dalam mengelola dan melestarikan alam. Salah satu kearifan tersebut dikenal dengan istilah mamar yang merupakan hutan milik kelompok masyarakat yang di dalamnya terdapat beberapa jenis tumbuhan yang dipercaya dapat melindungi ketersediaan sumber air serta mempunyai nilai magis religius. Sumu (dalam Openg: tanpa tahun) menyatakan bahwa mamar berperan penting dalam pelestarian hutan, menciptakan iklim mikro, dan konteks ekonomi. Bentuk kearifan lokal seperti nilai lokal masyarakat Timor dapat berupa menjunjung tinggi sikap menghormati, saling menghargai, toleransi, sopan santun, jujur, bertanggung jawab, bekerja keras, dan tidak melakukan tindakan yang merugikan orang lain. Keterampilan lokal seperti menenun, mengukir, dan menganyam juga merupakan salah satu bentuk kearifan lokal Timor. Kearifan lokal seperti itu perlu dilestarikan dan diperkenalkan kepada peserta didik dalam pembelajaran Bahasa Indonesia untuk mendukung program pendidikan karakter yang dirujuk dalam kurikulum 2013 dan menciptakan pembelajaran yang kontekstual.

Guru dapat menggunakan buku pengayaan atau referensi lainnya dan mengembangkan bahan ajar sendiri yang dapat digunakan dalam pembelajarann (Kemendikbud 2016). Pernyataan ini dapat dimanfaatkan guru untuk mengembangkan dan menyusun buku suplemen untuk menunjang buku utama yang diadakan Kemendibud dan penyusunanya dapat disesuaikan konteks lokal seperti memuat kearifan lokal. Namun, guru mengakui bahwa pengembangkan buku suplemen tidak mudah dilakukan dengan alasan masa transisi kurikulum yang terlalu cepat seperti kurikulum 2006 menuju kurikulum 2013 sampai revisi kurikulum 2013 pada tahun 2016. Selain itu, hambatan guru dalam mengembangkan buku suplemen yaitu keterbatasan waktu dan proses pengembangan yang tidak dikuasai oleh guru serta ketergantungan guru terhadap buku teks utama yang dibuat oleh Kemendikbud. Padahal Kemendikbud telah membuka peluang kepada guru agar dapat mengembangkan perangkat pembelajaran yang dapat memuat keunggulan lokal karena perangkat pembelajaran bersifat fleksibel dan kontekstual.

Tujuan kontekstualisasi dalam pembelajaran adalah agar peserta didik tetap berada pada budayanya, mengenal dan mencintai alam dan sosial di sekitarnya, dengan perspektif global sekaligus menjadi pewaris bangsa sehingga akan menjadi generasi tangguh dan berbudaya Indonesia (Kemendikbud 2016).

Berdasarkan observasi awal pada pembelajaran Bahasa Indonesia di SMK Negeri 1 Kefamenanu kabupaten Timor Tengah Utara menunjukkan hasil belum maksimal karena tidak mengkonkretkan kehidupan sosial budaya peserta didik dalam kegiatan pembelajaran. Guru hanya menggunakan buku teks yang diadakan Kemendikbud tanpa menggunakan buku sumber lain yang menyajikan konteks sosial budaya peserta didik sehingga dapat menunjang buku teks yang diadakan Kemendikbud. Buku teks yang diadakan Kemendikbud masih bersifat global sehingga kurang mewakili masalah yang nyata bagi peserta didik di Timor. Materi pelajaran dan kehidupan peserta didik kurang ada kesesuaian, sehingga transformasi ilmu pengetahuan dalam kehidupan peserta didik mengalami bias tujuan. Hal tersebut mengakibatkan peserta didik pasif dalam 
pembelajaran sehingga dampaknya berkelanjutan terhadap hasil belajar peserta didik yang kurang sesuai dengan apa yang diharapkan.

Berdasarkan kesenjangan pada kondisi pembelajaran bahasa Indonesia di Timor, perlu diadakan pengembangan buku teks dalam bentuk buku suplemen pada teks negosiasi bermuatan kearifan lokal Timor. Keputusan melakukan pengembangan buku suplemen yang memuat kearifan lokal Timor ini merupakan hasil analisis kebutuhan. Analisis kebutuhan sebagai perbedaan atau kesenjangan antara sesuatu yang terjadi dan sesuatu yang seharusnya terjadi (Gagne \& Briggs 1974). Peserta didik pada umumnya lebih membutuhkan pembelajaran yang bersifat kontekstual dengan memuat dinamika sosial budaya yang sedang berlangusung dalam lingkunganya. Dengan demikian peserta didik lebih termotivasi untuk terlibat aktif karena merasa tidak asing dalam pembelajaran. Pembelajaran yang kontekstual dapat menciptakan pembelajaran yang lebih menarik dan lebih dibutuhkan peserta didik (Rusman \& Pd 2012).

Pengembangan buku suplemen ini menggunakan pendekatan Content Language Integrative Learning (CLIL) dengan prinsip pembelajaran berbasis teks. CLIL merupakan suatu pendekatan pembelajaran yang berpusat pada dua hal yaitu materi dan bahasa dengan tujuan mendorong penguasaan materi sekaligus bahasa menuju tingkatan-tingkatan tertentu (Marsh et al. 2012) . Komponen pendekatan CLIL dalam pembelajaran meliputi (1) content (konten/materi), (2) communication (komunikasi), (3) cognition (proses berpikir), dan (4) culture (budaya) (Coyle 2008). Komponen CLIL ini diuraikan sebagai berikut. Content (materi) berkaitan dengan topik yang akan dipelajari (dalam hal ini misalnya topik IPA seperti ekosistem atau topik Bahasa Indonesia seperti teks negosiasi) (Kemendikbud 2015). Communication (komunikasi) berkaitan dengan penggunaan bahasa (misalnya membandingkan, melaporkan). Pada bagian ini konsep genre teraplikasi, bagaimana suatu jenis teks tersusun (struktur teks) dan bentuk bahasa apa yang sering digunakan pada jenis teks tersebut. Cognition (kognisi) berkaitan dengan keterampilan berpikir apa yang dituntut berkenaan dengan topik (misalnya mengidentifikasi, mengklasifikasi). Culture (kultur) berkaitan dengan muatan lokal lingkungan sekitar yang berkaitan dengan topik.

Komponen tersebut dikenal dengan 4C Framework for CLIL. Menurut 4C framework, belajar tidak hanya sebatas bagaimana peserta didik memahami konsep atau materi yang diajarkan, tetapi juga meliputi bagaimana proses belajar dan berpikir peserta didik dalam mengkonstruksi pengetahuan dan juga bagaimana peserta didik berkomunikasi dengan peserta didik lain dalam berbagai lingkungan sosial budaya.

Penelitian ini menggunakan pendekatan CLIL karena selain pendekatan CLIL merupakan rujukan utama dalam kurikulum 2013, pendekatan CLIL juga dapat mengembangkan kepercayaan diri peserta didik karena uraian materi bermuatan kebudayaan peserta didik sendiri mendorong pemahaman peserta didik terhadap kebudayaan peserta didik dalam hal ini kearifan lokal Timor serta meningkatkan keterampilan berkomunikasi dan keterampilan berpikir peserta didik karena komunikasi dan kognisi termasuk komponen dalam pendekatan CLIL.

Buku suplemen dikembangkan melalui prosedur tertentu. Perancang pembelajaran harus mengambil beberapa langkah untuk memilih, memodifikasi, atau mendesain bahan ajar, yaitu (1) menyiapkan kerangka kerja, (2) melakukan penelitian, (3) pemeriksaaan bahan ajar yang ada, (4) mengatur atau memodifikasi bahan yang ada, (5) mempersiapkan dan membuat bahan ajar, dan (6) memilih atau mempersiapkan kegiatan belajar (Rothwell \& Kazanas 2011). Model Four-D untuk prosedur pengembangan perangkat pembelajaran yang meliputi tahap pendefinisian (define), perencanaan (design), pengembangan (development), dan penyebaran (disseminate) (Trianto 2010). Prosedur pengembangan buku suplemen dalam penelitian ini menggunakan model Four-D yang dikemukakan oleh Thiagarajan, Semmel dan Semmel karena lebih sistematis dan lebih rinci sehingga memudahkan peneliti dalam mengembangkan buku suplemen.

Tujuan dilaksanakan pengembangan ini yaitu mendeskripsikan proses pengembangan buku suplemen teks negosiasi bermuatan kearifan lokal Timor dengan pendekatan CLIL dan mendeskripsikan kualitas pengembangan buku suplemen teks negosiasi bermuatan kearifan lokal Timor dengan pendekatan CLIL. Menurut Gagne dan Pety (dalam Muslich, 2010: 53), ada sepuluh kategori yang harus dipenuhi buku teks yang berkualitas yakni, (1) menarik peserta didik dalam menggunakanya, (2) mampu memberikan motivasi pada peserta didik yang menggunakannya, (3) memuat ilustrasi yang menarik, (4) mempertimbangkan aspek-aspek linguistik sehingga sesuai dengan kemampuan peserta didik, (5) isi berhubungan erat dengan pelajaran-pelajaran lain dan terencana sehingga sebagai satu kesatuan yang terpadu. (6) menstimulasi dan merangsang aktivitas pribadi pemakai, (7) Menghindari konsep-konsep yang samar dan tidak biasa agar pemakai tidak mengalami kebingungan, (8) memiliki sudut pandang yang tegas, (9) mampu memberi pemantapan dan penekanan pada nilainilai anak dan orang dewasa, dan (10) dapat menghargai perbedaan pribadi para pemakainya.

Aspek yang menjadi kriteria untuk menentukan kualitas hasil pengembangan produk yaitu, kevalidan, kepraktisan dan keefektifan (Nieveen et al. 1999). Kevalidan dikaitkan dengan dua hal, yaitu (1) produk pengembangan didasarkan pada rasional teori yang kokoh (validitas isi) dan (2) produk pengembangan saling berhubungan secara konsisten (validitas konstruk). Penentuan kevalidan pengembangan buku suplemen yang dikembangkan dalam penelitian ini ditentukan oleh para ahli dan pengguna buku suplemen (guru). Kepraktisan dikaitkan pada dua hal, yaitu (1) menurut ahli dan pengguna, produk yang dikembangkan harus dapat diterapkan dengan baik dan (2) secara operasional produk tersebut dapat digunakan. Dalam penelitian ini kepraktisan pengembangan buku suplemen dapat dilihat berdasarkan observasi keterlaksanaan RPP dalam 
kegiatan pembelajaran, serta repons guru dan respons peserta didik terhadap buku suplemen yang dikembangkan. Keefektifan buku teks dikaitkan pada dua hal, yaitu (1) menurut ahli dan pengguna produk yang dikembangkan ada konsistensi antara hasil yang dicapai dengan yang diharapkan dan (2) secara operasional ada kesesuaian antara hasil yang dicapai dengan yang diharapkan. Buku teks yang efektif tidak hanya memenuhi penilaian ahli, melainkan pengimplementasiannya dalam pembelajaran. Dalam penelitian ini, keefektifan buku suplemen dapat dilihat berdasarkan observasi aktivitas guru dan aktivitas peserta didik, serta ketuntasan hasil belajar peserta didik.

\section{METODE}

Jenis penelitian ini adalah Research and Development (R\&D) dengan menggunakan model FourD yang dikemukakan Thiagarajan, Semmel dan Semmel dengan modifikasi seuai kebutuhan menjadi tiga tahapan yaitu pendefinisian, perancangan, dan pengembangan. Subjek uji coba terbatas adalah siswa kelas X SMK Negeri 1 Kefamenanu, sedangkan subjek uji coba luas adalah siswa kelas X program keahlian Teknik Komputer dan Jaringan 1 SMK Negeri 1 Kefamenanu. Teknik pengumpulan data proses pengembangan yaitu observasi, sedangkan teknik pengumpulan data untuk kualitas pengembangan yaitu angket, observasi, dan tes.

Teknik angket bertujuan mengumpulkan data kelayakan isi, bahasa, penyajian, dan kegrafikaan buku suplemen yang berkaitan dengan aspek kevalidan dan mengumpulkan data respons guru dan respons peserta didik terhadap buku suplemen yang berkaitan dengan aspek kepraktisan. Teknik observasi bertujuan mengamati keterlaksanaan RPP yang berkaitan dengan aspek kepraktisan dan mengamati aktivitas guru dan peserta didik yang berkaitan dengan aspek keefektifan. Teknik tes bertujuan untuk mengumpulkan data ketuntasan hasil belajar peserta didik. Teknik analisis data proses pengembangan menggunakan teknik analisis deskriptif kualitatif. Teknik ini dilakukan dengan cara mengolah data yang berbentuk kalimat komentar dan saran yang dikemukakan oleh validator, guru dan peserta didik. Teknik penganalisisan data kualitas pengembangan buku suplemen terdiri atas teknik penganalisisan data kevalidan, kepraktisan dan keefektifan. Teknik penganalisisan data kevalidan buku suplemen dilakukan dengan cara menghitung skor jawaban dan tanggapan terhadap angket validasi. Teknik penganalisisan data kepraktisan buku suplemen dilakukan dengan cara mengolah observasi keterlaksanaan RPP, respons guru dan respons peserta didik. Teknik penganalisisan data keefektifan buku suplemen dilakukan dengan cara mengolah hasil observasi aktivitas guru dan peserta didik serta menghitung hasil ketuntasan belajar peserta didik.

\section{HASIL DAN PEMBAHASAN}

Hasil penelitian ini berupa hasil proses pengembangan buku suplemen dan hasil kualitas buku suplemen yang bermuatan kearifan lokal Timor dengan pendekatan CLIL.

\section{Proses Pengembangan Buku Suplemen}

Proses pengembangan meliputi tiga tahapan dari model Four-D, yaitu tahap pendefinisian, perancangan, dan pengembangan.

\subsection{Tahap Pendefinisian}

Tahap ini meliputi lima langkah, yaitu analisis awal, analisis peserta didik, analisis konsep, analisis tugas, dan perumusan tujuan pembelajaran. Hasil penelitian pada tahap pendefinisian dijelaskan sebagai berikut.

\subsubsection{Analisis Awal}

Hasil penelitian yang diperoleh pada langkah analisis awal adalah menganalisis masalah pembelajaran dan mengkaji kurikulum 2013. Masalah pembelajaran Bahasa Indonesia yang ditemukan berdasarkan observasi yaitu sebagai berikut. (1) Buku yang digunakan oleh guru dan peserta didik hanya buku teks yang diadakan oleh Kemendikbud sehingga kurang mewakili masalah nyata bagi peserta didik. (2) Peserta didik masih pasif dalam pembelajaran. Pada saat guru memberikan pertanyaan, hanya peserta didik yang sama yang berusaha untuk menjawab. Hal tersebut disebabkan peserta didik kurang termotivasi sehingga tidak memiliki rasa percaya diri untuk menjawab pertanyaan yang diberikan oleh guru. Rasa tidak percaya diri peserta didik diketahui dari pertanyaan guru tidak mau dijawab peserta didik pada saat guru bertanya secara individu, namun pertanyaan yang ditujukan secara kolektif, peserta didik menjawab secara beramai-ramai dengan benar. Kurangnya motivasi belajar peserta didik diketahui dari guru tidak memberikan motivasi pada kegiatan awal, kegiatan inti, maupun kegiatan penutup.

Berdasarkan temuan

masalah

pembelajaran tersebut, dapat diketahui pembelajaran Bahasa Indonesia belum maksimal. Dengan demikian dilakukan usaha perbaikan untuk mengatasi masalah tersebut melalui pengembangan sarana pelengkap sumber belajar bagi guru dan peserta didik berupa buku suplemen.

Pengembangan buku suplemen tersebut dilakukan untuk melengkapi buku teks utama dalam pembelajaran dan memotivasi peserta didik untuk belajar. Cara yang dilakukan untuk memotivasi peserta didik adalah dengan memuat kearifan lokal Timor dalam pemodelan teks yang merupakan basis dalam kurikulum 2013. Muatan kearifan lokal Timor dapat mewakili masalah yang nyata oleh peserta didik sehingga akan membantu peserta didik lebih cepat memahami materi pelajaran.

Pengembangan buku suplemen dalam penelitian ini merujuk pada kurikulum 2013. Oleh karena itu, selain menganalisis masalah pada langkah analisis awal, dilakukan pula analisis kurikulum yang akan dilakukan melalui kajian pustaka kurikulum 2013. Berdasarkan hasil kajian pustaka terkait kurikulum 2013, terdapat tiga kompetensi inti yaitu kompetensi inti ranah sikap (spiritual dan sosial), kompetensi inti ranah pengetahuan dan kompetensi inti ranah keterampilan. Kompetensi dasar yang tertuang dalam kurikulum 2013 merupakan penjabaran dari kompetensi inti ranah pengetahuan dan keterampilan, sedangkan kompetensi inti ranah sikap tidak dijabarkan karena kompetensi sikap dicapai melalui pembelajaran tidak langsung (indirect teaching). Materi 
pelajaran kelas $\mathrm{X}$ semester II adalah teks negosiasi, debat, cerita ulang/biografi, puisi, dan resensi buku. Setelah mengetahui materi yang terdapat dalam kurikulum 2013, kemudian ditentukan materi yang akan dikembangkan. Materi yang dipilih untuk dikembangkan dalam penelitian ini adalah materi teks negosiasi.

Pemilihan teks negosiasi dikarenakan teks tersebut berada pada semester II, sehingga bertepatan dengan perkiraan pelaksanaan uji coba. Selain itu pengetahuan dan keterampilan bernegosiasi perlu dibekali kepada peserta didik agar ketika terjun ke dalam masyarakat peserta didik dapat menerapkan penegtahuan dan keterampilan yang dimiliki tanpa rasa ragu atau takut dalam kegiatan negosiasi. Hal tersebut dianggap penting karena keterampilan bernegosiasi menentukan keberhasilan seseorang berkomunikasi. Materi teks negosiasi memiliki empat KD yang terdiri dari dua KD ranah pengetahuan dan dua KD ranah keterampilan.

Kajian selanjutnya adalah kajian terhadap pendekatan pembelajaran dalam kurikulum 2013. Hasil kajian ini diketahui bahwa pendekatan CLIL merupakan pendekatan yang menjadi rujukan utama dalam kurikulum 2013 (Kemendikbud 2016). Pendekatan ini dipilih dalam pengembangan buku suplemen teks negosiasi yang bermuatan kearifan lokal Timor. Kearifan lokal Timor yang dimuat dalam pengembangan buku suplemen termasuk dalam salah satu komponen dalam CLIL yakni komponen kultur.

\subsubsection{Analisis Peserta Didik}

Hasil penelitian yang diperoleh dari analisis peserta didik adalah tentang karakteristik peserta didik sebagai pengguna buku suplemen yang dikembangkan. Karakteristik peserta didik yaitu sebagai berikut. (1) Latar belakang ekonomi peserta didik berasal dari golongan menengah ke bawah. Hal tersebut dapat diketahui dari rata-rata pekerjaan orang tua dari peserta didik yaitu petani dan peternak. (2) Sebagian besar peserta didik berasal dari pulau Timor. (3) Peserta didik mempunyai kemampuan yang heterogen. Kemampuan akademik peserta didik diperoleh melalui nilai harian. (4) Peserta didik memiliki motivasi belajar yang rendah. Hal ini dilihat dari sikap pasif peserta didik dalam pembelajaran yang menggunakan model pembelajaran konvensional dengan metode ceramah dan kurangnya pemanfaatan perpustakaan sekolah pada waktu luang atau istirahat. Kurangnya motivasi belajar oleh peserta didik, dapat mengakibatkan minimnya pengalaman belajar.

Berdasarkan data karakteristik peserta didik tersebut, pengembangan buku suplemen teks negosiasi yang bermuatan kearifan lokal disesuaikan dengan karakteristik peserta didik. Berdasarkan kehidupan sosial ekonomi peserta didik, maka teks yang memuat kearifan lokal Timor dalam pengembangan buku suplemen ini menggambarkan kehidupan masyarakat menengah ke bawah. Untuk menciptakan pembelajaran yang efektif, tugas yang ditetapkan akan disajikan dengan lebih banyak dikerjakan peserta didik melalui kerja kelompok agar peserta didik yang kurang mampu dibantu peserta didik yang mampu. Selain itu, hal tersebut juga dimaksudkan melatih keterampilan berkomunikasi peserta didik dalam kegiatan diskusi karena salah satu komponen dalam pendekatan CLIL adalah "komunikasi".

Berdasarkan informasi karakteristik peserta didik yang memiliki motivasi belajar yang rendah, pengembangan buku suplemen ini memuat budaya peserta didik sendiri sehingga dapat meningkatkan minat peserta didik dalam kegiatan pembelajaran. Selain itu, buku suplemen ini didesain dengan menggunakan variasi warna yang menarik agar meningkatkan motivasi peserta didik untuk membaca dan mempelajari buku tersebut.

\subsubsection{Analisis Konsep}

Hasil penelitian yang diperoleh dari analisis konsep adalah informasi tentang materi-materi yang digunakan sebagai sarana pencapaian KI-KD. Materi yang dijabarkan dari KD yaitu (1) ciri-ciri teks negosiasi, (2) sikap bernegosiasi, (3) strategi bernegosiasi, (4) teks negosiasi tulis, (5) struktur teks negosiasi, (6) ciri kebahasaan teks negosiasi, dan (7) langkah-langkah menyusun teks negosiasi. Materi-materi tersebut yang akan dirancang pada buku suplemen yang dikembangkan.

Materi yang ditentukan tersebut didasarkan pada kompetensi dasar untuk mencapai syarat kelengkapan isi. Materi-materi tersebut disusun secara sistematis agar memudahkan pemahaman peserta didik terhadap buku suplemen yang dikembangkan. Penyajian materi tersebut dimulai dari informasi berupa pengetahuan negosiasi baru disusul informasi berupa keterampilan negosiasi karena pemahaman terhadap pengetahuan merupakan landasan memiliki keterampilan negosiasi.

\subsubsection{Analisis Tugas}

Hasil penelitian yang diperoleh dari analisis tugas adalah informasi tentang tugas-tugas belajar pada kompetensi dasar pengetahuan dan keterampilan yang dilakukan peserta didik untuk menciptakan kondisi belajar.

Hasil analisis tugas yaitu sebagai berikut. (1) Materi ciri-ciri teks negosiasi memiliki tugas mendiskusikan isi teks dan merumuskan ciri-ciri teks negosiasi. (2) Materi sikap bernegosiasi memiliki tugas menyunting teks negosiasi berdasarkan sikap-sikap yang diharapkan dalam bernegosiasi dan memeragakan hasil suntingan teks negosiasi. Selanjutnya diberikan tugas mengevaluasi teks negosiasi. (3) Materi strategi bernegosiasi memiliki tugas melakukan praktik bernegosiasi dengan menggunakan strategi umum maupun khusus. (4) Materi teks negosiasi tulis memiliki tugas melengkapi teks negosiasi tulis. (5) Materi struktur teks negosiasi memiliki tugas menganalisis struktur teks negosiasi. (6) Materi ciri kebahasaan teks negosiasi memiliki tugas mengidentifikasi cirri kebahasaan teks negosiasi. (7) Materi langkah-langkah menyusun teks negosiasi memiliki tugas menyusun teks negosiasi baik secara berkelompok maupun secara individu.

\subsubsection{Perumusan Tujuan Pembelajaran}

Hasil penelitian yang diperoleh dari perumusan tujuan pembelajaran adalah informasi tentang tujuan pembelajaran dengan menggunakan buku suplemen yang dikembangkan.

Hasil perumusan tujuan pada kompetensi pengetahuan dan keterampilan yaitu peserta didik mampu; (1) mengidentifikasi ciri-ciri teks negosiasi, (2) 
menilai cara menyampaikan pengajuan, penaawaran, dan persetujuan dalam teks negosiasi, (3) menggunakan strategi bernegosiasi, (4) melegkapi teks negosiasi tulis, (5) menemukan struktur teks negosiasi, (6) menemukan ciri kebahasaan teks negosiasi, (7) menyusun teks negosiasi secara berkelompok, dan (8) menyusun teks negosiasi secara mandiri.

\subsection{Tahap Perancangan}

Hasil tahap perancangan meliputi tahap memilih media, memilih format, dan mendesain produk.

\subsubsection{Memilih Media}

Kegiatan memilih media dilakukan untuk menyeleksi bahan yang digunakan pada buku suplemen yang dikembangkan seperti teks, foto dan bagan. Teks yang terdapat pada buku "Bahasa Indonesia" dari Kemendikbud kurang relevansi dengan keadaan di Timor, sehingga hasil dari kegiatan memilih teks teks dalam pengembnagan buku suplemen ini yaitu memilih teks yang memuat kearifan lokal Timor yang meliputi teks Membeli Kain Tenun, Mari ke Gunung Batu Marmer, Meminta Ijin Belajar Kelompok, Membeli Dendeng Timor, Penawaran Buah Jeruk Keprok So'e, Pelaksanaan Program Demplot, dan Mengembangkan Usaha Madu. Media teks yang dipilih kemudian dilakukan validasi terhadap teks tersebut oleh budayawan Timor yang bernama Yance Bana. Validasi dilakukan untuk mengetahui tingkat kelayakan teks yang memuat kearifan lokal Timor untuk menghindari ketidaksesuaian kearifan lokal Timor yang terdapat pada teks. Hasil validasi menunjukkan teks yang dipilih sebagai media termasuk dalam kategori sangat layak. Hal tersebut didukung oleh komentar budayawan tersebut bahwa teks yang dipilih benar-benar memuat kearifan lokal Timor yang terdapat pada lampiran. Dengan demikian, teks yang telah divalidasi dapat disajikan dalam buku suplemen yang dikembangkan.

Foto yang digunakan adalah foto peserta didik yang sedang berpose dengan mengenakan seragam SMA dengan pusat pandang tertuju pada kamera dan foto dua orang yang sedang berjabatangan dengan mengenakan jas. Foto peserta didik yang menggunakan seragam SMA dimaksudkan untuk menggambarkan kepada pembaca bahwa buku suplemen ini ditujukan kepada peserta didik yang duduk di bangku SMA. Sedangkan foto dua orang yang sedang berjabatangan dimaksudkan untuk menggambarkan isi (konten) buku tersebut yaitu materi teks negosiasi. Berjabatangan menandakan adanya suatu kesepakatan dalam kegiatan bernegosiasi. Dengan demikian, foto tersebut dapat memberikan gambaran tentang isi buku karena kesesuaian foto dan isi buku suplemen yang dikembangkan. Kedua foto tersebut digunakan pada sampul buku.

Selain foto yang digunakan pada sampul buku, digunakan pula foto seorang ibu yang sedang membeli kain tenun yang digunakan untuk mempertegas teks "Membeli Kain Tenun", foto tiga orang anak sekolah yang sedang berdiskusi untuk mempertegas teks "Mari ke Gunung Batu Marmer", foto seorang anak yang sedang berbincang dengan ayahnya untuk mempertegas teks "Meminta Izin Belajar Kelompok", dan foto seorang bapak yang sedang membeli dendeng Timor untuk mempertegas teks "Membeli Dendeng Timor". Foto-foto tersebut digunakan pada isi buku suplemen.

Bagan digunakan pada penjelasan materi. Bagan yang digunakan dipilih dari aplikasi SmartArt agar memudahkan pemehaman peserta didik mengenai materi yang dipelajari. Materi yang menggunakan bagan yaitu strategi bernegosiasi, struktur teks negosiasi, ciri bahasa teks negosiasi, dan langkah menyusun teks negosiasi.

\subsubsection{Memilih Format}

Kegiatan memilih format dilakukan untuk mempelajari dan menentukan hasil yang menjadi dasar dan bahan buku seperti menetapkan komposisi halaman, menetapkan jenis huruf dan spasi, menetapkan penggunaan warna pada huruf, menetapkan warna dasar buku, meletakan penomoran pada setiap halaman, dan menetapkan jenis kertas.

Hasil rancangan memilih format yaitu sebagai berikut. (1) Pada umumnya huruf yang digunakan berukuran sembilan dengan jenis huruf Arial, namun pada beberapa komponen seperti judul, sub judul pembelajaran, judul teks, kata "tugas", dan kata "rangkuman materi" memiliki ukran huruf lebih besar yaitu antara 12 sampai 16 dengan jenis huruf arial dan adapun yang menggunakan jenis huruf Calisto MT. Variasi huruf dan jenis huruf tesebut dilakukan agar komposisi halaman buku terkesan tidak kaku dan lebih menarik. (2) Spasi yang ditetapkan adalah 1,5. (3) Penetapan warna latar buku yaitu hijau dan oranye. Warna dasar tersebut dipilih untuk menggambarkan keadaan alam di Timor. Secara geografis, Timor memiliki wilayah berupa tanah kering dan berbukit-bukit gundul sehingga Timor dikenal sebagai daerah yang gersang. Berdasarkan pengetahuan alam tesebut, masyarakat Timor memiliki suatu kearifan lokal yaitu menjaga dan melestarikan alam untuk melindungi sumber daya air dan menunjang perekonomian masyarakat. Dengan demikian, warna oranye yang digunakan sebagai warna latar buku suplemen menggambarkan wilayah Timor yang kering dan gersang, sedangkan warna hijau menggambarkan kearifan lokal Timor yaitu melestarikan alam. (4) Penggunaan warna huruf yaitu hitam, putih, dan oranye. Pemilihan warna tersebut disesuaikan dengan warna latar buku suplemen agar terlihat jelas dan harmonis. (5) Peletakan nomor halaman di sudut kiri dan sudut kanan bawah buku. (6) Jenis kertas yang digunakan adalah B5 80gr. Ukuran kertas tersebut disesuaikan dengan ketebalan buku atau jumlah halaman buku.

\subsubsection{Mendesain Produk Awal}

Hasil dari tahap ini adalah desain awal buku suplemen teks negosiasi yang bermuatan kearifan lokal Timor dengan pendekatan CLIL. Kegiatan yang menghasilkan desain awal buku suplemen meliputi (1) menentukan judul buku dan membuat desain sampul buku, (2) menentukan sistematika buku, (3) menulis konten buku, (4) mengevaluasi dan mengedit.

Judul buku yang ditetapkan adalah "Kearifan Lokal dalam Teks Negosiasi". Judul ini dipilih berdasarkan konten buku yang memuat kearifan lokal masyarakat Timor dalam teks negosiasi misalnya teks "Membeli Kain Tenun". Teks ini memuat kearifan lokal Timor yaitu keterampilan menenun. Selanjutnya, dilakukan penyusunan sistematika buku suplemen sesuai 
dengan urutan KD, kemudian menulis konten buku. Kegiatan menulis konten buku disesuaikan dengan sistematika yang telah ditentukan. Penulisan konten buku juga menggunakan media dan format yang telah ditetapkan. Tahap selanjutnya yaitu mengevaluasi dan mengedit. Dalam kegiatan evaluasi ditemukan masih ada kesalahan dan kekeliruan penulisan sehingga dilakukan perbaikan tulisan yang masih salah ataupun keliru. Hasil revisi pada tahap ini menghasilkan draf I produk pengembangan.

\subsection{Tahap Pengembangan}

Tahap pengembangan ini menghasilkan produk pengembangan yang dilakukan melalui lima tahapan yaitu validasi produk awal buku suplemen, revisi, uji coba, pengoreksian buku suplemen, dan validasi produk final buku suplemen. Tahap uji coba dilakukan dua kali yaitu uji coba terbatas dan uji coba luas di SMK Negeri 1 Kefamenanu.

\subsubsection{Tahap Validasi Produk Awal Buku}

Suplemen Berdasarkan penilaian validator, terdapat komentar dan saran terhadap buku suplemen yang dikembangkan dalam penelitian ini agar dapat menghasilkan produk yang lebih baik. Komentar tersebut terdapat pada angket validasi isi, kebahasaan,penyajian, dan kegrafikaan yang diperoleh dari tiap validator.

Validator aspek isi buku suplemen memberi komentar dan saran yaitu (1) secara umum buku suplemen yang dikembangkan sudah baik dan layak digunakan, (2) perlu dipertegas penerapan pendekatan CLIL dalam pengantar atau pendahuluan, (3) perlu adanya seting pada setiap teks agar menampakkan komponen kultur sebagai salah satu komponen pendekatan CLIL, dan (4) perlu perbaikan tulisan yang kurang jelas karena efek warna yang terlalu kuat.

Validator aspek penyajian buku suplemen memberi komentar dan saran bahwa (1) buku sulemen yang dikembangkan sudah baik dan layak digunakan, (2) pewarnaan terlalu kuat sehingga mengakibatkan tulisan kurang jelas, (3) rincian sebaiknya bernomor, dan (4) penomoran pada tugas kurang konsisten.

Validator aspek kebahasaan buku suplemen memberi saran agar memperhatikan pemanfaatan Lembar Kerja Peserta Didik (LKPD). Selain itu, tidak ditemukan komentar pada lembar angket tentang penggunaan bahasa dalam buku yang dikembangkan.

Validator aspek kegrafikaan buku supleman memberi saran yaitu, (1) ilustrasi sampul peserta didik diganti dengan ilustrasi peserta didik yang sedang beraktivitas dan ilustrasi sampul berjabatangan disesuaikan dengan topik buku, (2) perlu diperbaiki tata letak tabel, (3) gambar ilustrasi pada isi harus lebih jelas, dan (4) ukuran huruf perlu dipertimbangkan.

\subsubsection{Tahap Revisi}

Aspek yang direvisi berdasarkan komentar validator isi yaitu mempertegas pendekatan CLIL dalam kata pengantar dan mengganti warna hruf putih dengan hitam sehingga lebih jelas. Aspek yang direvisi berdasarkan komentar validator penyajian: menggunakan penomoran pada rincian. Aspek yang direvisi berdasarkan komentar validator: mengganti gambar ilustrasi sampul, memperbaiki tata letak tabel, ukuran huruf diganti dengan ukuran 12 dan ukuran kertas B5 diganti dengan ukuran kertas A4 sehingga gambar ilustrasi dengan sendirinya tampak lebih jelas. Hasil revisi pada tahap ini menghasilkan draf II produk pengembangan.

\subsubsection{Tahap Uji Coba}

Tahap ini terdiri dari dua tahap yaitu uji coba terbatas dan uji coba luas. Uji coba terbatas dilakukan untuk mengidentifikasi kekurangan-kekurangan buku suplemen yang dikembangkan melalui komentar yang diberikan guru dan peserta didik. Menurut komentar guru, buku suplemen yang dikembangkan sudah baik dan sangat cocok untuk peserta didik, namun masih perlu meninjau kembali penulisan yang salah. Secara umum, guru memberikan respons yang sangat baik terhadap buku suplemen. Demikian juga respons yang diberikan oleh peserta didik. Peserta didik menyatakan bahwa buku buku suplemen ini memuat mereka termotivasi untuk belajar karena memuat budaya peserta didik sendiri yaitu kearifan lokal Timor dan memiliki desain buku yang menarik. Di samping itu, adapun komentar dari peserta didik mengenai tata letak tulisan yang tidak sesuai yaitu pada teks.

Berdasarkan tanggapan guru terhadap penyempurnaan buku suplemen, tahap selanjutnya yang dilakukan adalah tahap revisi. Aspek yang direvisi adalah penulisan kata-kata salah dan tata letak yang tidak sesuai. Setelah merevisi, buku suplemen siap untuk diujicobakan pada tahap berikutnya yaitu uji coba luas. Hasil revisi pada tahap ini menghasilkan draf III produk pengembangan.

Selanjutnya dilakukan uji coba luas untuk mengidentifikasi kepraktisan dan keefektifan buku suplemen yang dikembangkan. Kepraktisan buku suplemen diperoleh dari observasi keterlaksanaan RPP, respons guru, dan respons peserta didik terhadap buku suplemen yang dikembangkan. Keefektifan buku suplemen diperoleh dari aktivitas guru, aktivitas peserta didik dan tes hasil belajar.

Pelaksanaan pembelajaran disesuaikan dengan rencana pelaksanaan pembelajaran yang telah dibuat. Untuk pelaksanaan uji coba, digunakan lembar observasi keterlaksanaan RPP utuk mengetahui tingkat keterlaksanaan RPP. Adapun tanggapan pengamat pada pertemuan ke-1 yang termuat dalam kolom komentar dan saran perbaikan tentang keterlaksanaan RPP yaitu sebagai berikut. (1) Pada awal pembelajaran peserta didik perlu diberi motivasi. (2) Pada kegiatan peragaan teks, jangan hanya dilakukan oleh perwakilan kelompok melainkan seluruh peserta didik perlu dilibatkan karena waktu sangat cukup untuk mengakomodasi seluruh peserta didik memeragakan teks negosiasi sehinggga komponen komunikasi dialami oleh seluruh peserta didik. Hasil dari tanggapan pengamat tersebut, kemudian peneliti merevisi RPP untuk pertemuan ke-2 dan pertemuan ke-4 yang memiliki kegiatan memeragakan teks, dengan melibatkan seluruh peserta didik dalam kegiatan peragaan teks dan menambahkan kegiatan motivasi pada kegiatan pendahuluan pada pertemuanpertemuan berikutnya.

Selain tanggapan tentang keterlaksanaan RPP, diperoleh juga tanggapan yang ditemukan dalam kolom 
komentar dan saran tentang aktivitas guru dan aktivitas peserta didik. Tanggapan tentang aktivitas guru didik ditemukan pada lembar observasi aktivitas guru pada pertemuan ke-1 yaitu sebagai berikut (1) guru seharusnya memberi kesempatan kepada seluruh peserta didik untuk memeragakan teks. (2) guru seharusnya memberikan penghargaan kepada peserta didik yang mempresentasikan tugas dengan benar atau menjawab pertanyaan dengan benar sehingga peserta didik tetap semangat dalam pembelajaran karena waktu pembelajaran cukup lama. Hasil dari tanggapan pengamat tersebut, kemudian guru memberi kesempatan kepada seluruh peserta didik untuk memeragakan teks dan memberi penghargaan kepada peserta didik yang mempresentasikan tugas dengan benar pada pertemuan ke-2, pertemuan ke-3, dan pertemuan ke-4. Selanjutnya, tanggapan pengamat tentang aktivitas peserta didik ditemukan pada lembar observasi aktivitas peserta didik pada pertemuan ke-1 yaitu pembagian kelompok dilakukan secara heterogen sehingga keaktifan kelompok merata. Hasil dari tanggapan tersebut, guru membagi peserta didik dalam kelompok secara heterogen pada pertemuan ke-2, pertemuan ke-3, dan pertemuan ke-4 dan hasilnya cukup efektif. Pada lembar observasi aktivitas peserta didik pada ketemuan ke-4 juga ditemukan tanggapan pengamat yaitu aktivitas peserta didik sudah sangat baik.

Selain hasil keterlaksanaan RPP, hasil aktivitas guru dan hasil aktivitas peserta didik, diperlukan juga respons guru dan respons peserta didik terhadap buku suplemen agar dapat menunjang ukuran kepraktisan dan keefektifan buku suplemen yang dikembangkan. Respons guru dan respons peserta didik diperoleh dari komentar dan saran yang terdapat pada angket respons. Hasil angket respons diperoleh dari guru bahasa Indonesia sebagai pengguna buku suplemen pada tahap uji coba luas. Hasil respons peserta didik diperoleh dari 31 peserta didik yang mengisi angket respons, kemudian mengklasifikasikan tanggapan peserta didik. Hal tersebut dilakukan sebab sebaian besar peserta didik memberikan tanggapan yang sama.

Respons guru terhadap buku suplemen yang terdapat pada komentar dan saran angket respons yaitu sebagai berikut. (1) Buku suplemen yang dikembangkan sudah baik dan sangat cocok untuk peserta didik karena bermuatan kearifan lokal Timor yang merupakan budaya peserta didik itu sendiri. (2) Buku suplemen yang dikembangkan dapat meningkatkan keaktifan peserta didik dalam kegiatan pembelajaran. Selain respons guru, adapun respons peserta didik terhadap buku suplemen yang dikembangkan. Respons peserta didik yaitu sebagai berikut. (1) Buku yang dikembangkan sangat bagus dan unik karena memuat budaya Timor. (2) Desain buku menarik. (3) Buku yang dikembangkan memiliki kualitas yang sempurna dan sangat bermutu. (4) Buku yang dikembangkan dapat meningkatkan motivasi. (5) Topik teks negosiasi pada halaman 18 poin ke-5 tidak memuat budaya Timor.

Berdasarkan respons peserta didik tersebut, maka dilakukan revisi yaitu topik teks negosiasi pada halaman 18 poin ke-5 diganti dengan topik yang memuat kearifan lokal Timor. Dengan demikian, topik teks negosiasi pada mulanya yaitu "menawar sewa kendaraan untuk kegiatan pramuka di luar kota kemudian diganti dengan topik teks negosiasi "menawar lokasi penghijauan di dalam kota kepada ketua panitia kegiatan peduli lingkungan". Topik ini memuat kearifan lokal yaitu masyarakat Timor selalu berusaha untuk melestarikan alam karena daerah Timor merupakan daerah yang gersang dan memiliki debit air yang sedikit. Hasil revisi pada tahap ini menghasilkan draf IV produk pengembangan.

\subsubsection{Tahap Pengoreksian Buku Suplemen}

Pengoreksian buku suplemen merupakan kegiatan mengoreksi kekurangan-kekurangan yang masih terdapat dalam buku suplemen yang dikembangkan setelah melalui tahap uji coba di lapangan. Pengoreksian buku suplemen dilakukan oleh dosen penguji penelitian dan pengembangan dengan cara memberikan komentar untuk perbaikan buku suplemen sehingga sesuai dengan yang diharapkan.

Hasil koreksi buku suplemen yang telah diujicoba yaitu sebagai berikut. (1) Tanda baca belum sesuai dengan ejaan yang disempurnakan. (2) Bahasa yang digunakan

pada judul buku, judul pelajaran, dan sub judul pelajaran terlalu formal, sehingga perlu diperbaiki dengan menggunakan bahasa yang lebih santai agar lebih komunikatif dengan peserta didik. Hal yang direvisi yaitu menggunakan tanda baca yang sesuai dengan ejaan yang disempurnakan dan memperbaiki penggunaan bahasa yang lebih komunikatif pada judul buku, judul pelajaran, dan sub judul pelajaran. Revisi tersebut menghasilkan produk final buku seplemen (draf V). Revisi penggunaan bahasa dapat dilihat pada tabel berikut.

Tabel 1 Hasil Revisi Penggunaan Bahasa pada Judul Buku, Judul dan Sub Judul Pelajaran

\begin{tabular}{|c|c|c|c|}
\hline No & Aspek & Sebelum Revisi & Sesudah Revisi \\
\hline \multirow[t]{4}{*}{1} & Judul & Kearifan Lokal & Membahasakan \\
\hline & Buku & Timor dalam & Budayamu (Muatan \\
\hline & & Teks Negosiasi & Kearifan Lokal \\
\hline & & & $\begin{array}{c}\text { Timor dalam Teks } \\
\text { negosiasi) }\end{array}$ \\
\hline \multirow[t]{12}{*}{2} & Judul dan & Menilai Cara & Mari Mengenal \\
\hline & Sub Judul & Bernegosiasi & Teks Negosiasi \\
\hline & Pelajaran & & dan Berlatih \\
\hline & 1 & & Menilai Cara \\
\hline & & & Bernegosiasi \\
\hline & & A. Menemukan & A. Apa Tanda Teks \\
\hline & & Ciri-Ciri Teks & Negosiasi? \\
\hline & & Negosiasi & B. Mari Menilai \\
\hline & & B. Menilai Cara & Cara \\
\hline & & Menyampaika & Beregosiasi \\
\hline & & $\begin{array}{c}\text { n Pengajuan, } \\
\text { Penawaran, } \\
\text { dan }\end{array}$ & \\
\hline & & Persetujuan & \\
\hline \multirow[t]{4}{*}{3} & Judul dan & Menyampaikan & Mari Bernegosiasi \\
\hline & Sub Judul & Pengajuan, & \\
\hline & Pelajaran & Penawaran, dan & \\
\hline & 2 & Persetujuan & \\
\hline
\end{tabular}




\begin{tabular}{|c|c|c|c|}
\hline No & Aspek & Sebelum Revisi & Sesudah Revisi \\
\hline \multirow{3}{*}{4} & & $\begin{array}{c}\text { dalam Teks } \\
\text { Negosiasi } \\
\text { A. Menggunakan } \\
\text { Strategi dalam } \\
\text { Bernegosiasi } \\
\text { B. Melengkapi } \\
\text { Teks } \\
\text { Negosiasi } \\
\text { Tulis }\end{array}$ & $\begin{array}{c}\text { A. Inilah Strategi } \\
\text { dalam Teks } \\
\text { Negosiasi } \\
\text { B. Lengkapilah } \\
\text { Teks Negosiasi } \\
\text { Tulis! }\end{array}$ \\
\hline & $\begin{array}{c}\text { Judul dan } \\
\text { Sub Judul } \\
\text { Pelajaran } \\
3\end{array}$ & $\begin{array}{l}\text { Menganaisis } \\
\text { Struktur dan Ciri } \\
\text { Kebahasaan } \\
\text { Teks Negosiasi }\end{array}$ & $\begin{array}{c}\text { Inilah Susunan } \\
\text { dan Ciri Bahasa } \\
\text { Teks Negosiasi }\end{array}$ \\
\hline & & $\begin{array}{l}\text { A. Menemukan } \\
\text { Struktur Teks } \\
\text { Negosiasi } \\
\text { B. Menemukan } \\
\text { Ciri } \\
\text { Kebahasaan } \\
\text { Teks } \\
\text { Negosiasi }\end{array}$ & $\begin{array}{c}\text { A. Inilah Susunan } \\
\text { Teks Negosiasi } \\
\text { B. Inilah Ciri } \\
\text { Bahasa Teks } \\
\text { Negosiasi }\end{array}$ \\
\hline \multirow[t]{2}{*}{5} & $\begin{array}{l}\text { Judul dan } \\
\text { Sub Judul } \\
\text { Pelajaran }\end{array}$ & $\begin{array}{c}\text { Menyusun Teks } \\
\text { Negosiasi }\end{array}$ & $\begin{array}{c}\text { Mana Teks } \\
\text { Negosiasimu? }\end{array}$ \\
\hline & 4 & $\begin{array}{l}\text { A. Menyusun } \\
\text { Teks } \\
\text { Negosiasi } \\
\text { secara } \\
\text { Berkelompok } \\
\text { B. Menyusun } \\
\text { Teks } \\
\text { Negosiasi } \\
\text { secara } \\
\text { Mandiri }\end{array}$ & $\begin{array}{l}\text { A. Ayo, Susunlah } \\
\text { Teks Negosiasi } \\
\text { Bersama! } \\
\text { B. Ayo, Susunlah } \\
\text { Teks Negosiasi } \\
\text { secara Mandiri! }\end{array}$ \\
\hline
\end{tabular}

\subsubsection{Tahap Validasi Produk Final Buku} Suplemen

Berdasarkan penilaian validator, ditemukan komentar terhadap buku suplemen yang dikembangkan. Komentar tersebut terdapat pada angket validasi isi, penyajian, dan kegrafikaan yang diperoleh dari tiap validator. Validator aspek isi buku suplemen memberi komentar yaitu materi sudah lengkap, mendalam, dan akurat. Validator aspek isi buku suplemen memberi komentar, yaitu cara penyajian buku sangat layak. Validator aspek kebahasaan buku suplemen memberi komentar, yaitu tidak ada revisi. Sedangkan, untuk aspek kebahasaan, tidak ditemukan komentar terhadap buku suplemen yang dikembangkan.

Berdasarkan komentar dari validator, tidak ditemukan komentar yang mengarahkan perbaikan pada buku suplemen yang dikembangkan. Validator isi memberikan penegasan bahwa materi sudah lengkap, mendalam, dan akurat. Ketiga hal tersebut termasuk kriteria kelayakan isi buku teks berdasarkan BSNP. Dengan demikian buku yang dikembangkan, telah memenuhi kriteria tersebut. Validator penyajian memberikan komentar bahwa cara penyajian buku suplemen sudah layak. Hal tersebut sesuai dengan kriteria kelayakan buku teks berdasarkan BSNP. Dengan demikian, dari segi penyajian sudah layak. Validator kegrafikaan juga memberi komentar bahwa dari segi kegrafikaan, tidak ada revisi. Hal ini membuktikan bahwa kegrafikaan buku suplemen yang dikembangkan sudah layak digunakan.

\section{Kualitas Pengembangan Buku Suplemen}

Hasil kualitas buku suplemen meliputi kevalidan, kepraktisan, dan keefektifan. Kevalidan buku suplemen dilakukan pada dua tahap yaitu validasi produk awal sebelum uji coba buku suplemen (tahap-I) dan validasi produk final sesudah uji coba buku supleme (tahap-II). Validasi buku suplemen dilakukan oleh ahli dan pengguna buku suplemen(guru). Validasi buku suplemen terdiri dari validasi isi, bahasa, penyajian, dan kegrafikaan. Hasil validasi isi pada tahap-I menunjukkan nilai $94 \%$, sedangkan tahap-II menujukkan nilai $98 \%$. Hasil validasi bahasa pada tahap-I menunjukkan nilai $75 \%$, sedangkan tahap-II menunjukkan nilai $80 \%$. Hasil validasi penyajian tahap-I menunjukkan hasil $96 \%$, sedangkan tahap-II menunjukkan nilai $98 \%$. Hasil validasi kegrafikaan tahap-I menunjukkan nilai $94 \%$, sedangkan tahap-II menunjukkan nilai $98 \%$. Degan demikian rerata hasil validasi buku suplemen tahap I menunjukkan nilai $90 \%$ dengan kategori sangat layak, sedangkan tahap-II menunjukkan nilai $94 \%$ dengan kategori sangat layak.

Penentuan kriteria kelayakan buku suplemen menggunakan hasil validasi produk final buku suplemen yaitu pada tahap-II karena produk final buku suplemen telah melewati beberapa tahapan revisi. Dengan demikian, hasil validasi buku suplemen teks negosiasi bermuatan kearifan lokal Timor dengan pendekatan CLIL menunjukkan hasil 94\% dengan kategori sangat layak sehingga dapat disimpulkan buku suplemen tersebut dapat digunakan dalam pembelajaran Bahasa Indonesia bagi guru dan peserta didik di Timor.

Kepraktisan buku suplemen diukur melalui keterlaksanaan RPP, respons guru, dan respons peserta didik. Berdasarkan hasil observasi, hasil keterlaksanaan RPP menunjukkan nilai $83 \%$ dengan kategori baik. Respons guru dan peserta didik terhadap buku suplemen diperoleh dari angket yang diberikan. Respons guru terhadap buku suplemen menunjukkan nilai $85 \%$ dengan kategori sangat baik dan respons peserta didik terhadap buku suplemen menunjukkan nilai $85 \%$ dengan kategori sangat baik. Dengan demikian, buku suplemen teks negosiasi bermuatan kearifan lokal Timor dengan pendekatan CLIL memiliki kategori sangat praktis untuk digunakan dalam pembelajaran Bahasa Indonesia oleh guru dan peserta didik di Timor.

Keefektifan buku suplemen diukur melalui aktivitas guru, aktivitas peserta didik, dan tes hasil belajar peserta didik. Berdasarkan hasil observasi, aktivitas guru menunjukkan hasil $86 \%$, sedangkan hasil peserta didik $81 \%$. Berdasarkan teknik tes, hasil belajar peserta didik menunjukkan nilai rerata kelas yaitu mencapai nilai 81 dengan kategori tuntas. Dengan demikian, buku suplemen teks negosiasi bermuatan kearifan lokal Timor dengan pendekatan CLIL memiliki kategori sangat efektif 
untuk digunakan dalam pembelajaran Bahasa Indonesia oleh guru dan peserta didik di Timor.

\section{PENUTUP}

\section{Simpulan}

Proses pengembangan buku suplemen teks negosiasi yang bermuatan kearifan lokal Timor dengan pendekatan CLIL yang terdiri dari tahap pendefinisian, perancangan, dan pengembangan terlaksana tanpa terkecuali. Proses pengembangan menghasilkan buku suplemen dengan kategori sangat layak, sangat praktis dan sangat efektif untuk digunakan sebagai pendamping buku pelajaran Bahasa Indonesia kelas X semester II. Berdasarkan hasil kevalidan, kepraktisan dan keefektifan buku suplemen yang dikembangkan, maka dapat disimpulkan bahwa buku suplemen "Membahasakan Budayamu (Muatan Kearifan Lokal Timor dalam Teks Negosiasi” yang dikembangkan ini berkualitas. Oleh karena itu, buku tersebut dapat digunakan sebagai pendamping buku utama "Bahasa Indonesia" yang diadakan Kemendikbud oleh peserta didik di Timor dalam kegiatan pembelajaran karena buku tersebut dapat meningkatkan motivasi belajar peserta didik.

\section{Saran}

Berdasarkan hasil penelitian, saran peneliti yaitu sebagai berikut. (1) Buku suplemen teks negosiasi yang bermuatan kearifan lokal Timor dengan pendekatan CLIL dapat diterapkan dalam pembelajaran Bahasa Indonesia bagi guru di Timor. Dalam buku yang dikembangkan ini, sudah terdapat komponen yang kompleks seperti terdapat teori, kegiatan pembelajaran, dan evaluasi, namun guru sebaiknya tetap menggunakan buku teks utama "Bahasa Indonesia" yang diadakan Kemendikbud sehingga proses pembelajaran lebih kompleks karena menggambarkan perspektif global dan kondisi lokal. Selain itu, guru sebaiknya tidak hanya berpatokan pada metode yang telah dituangkan dalam buku ini seperti bermain peran, diskusi, dan tanya jawab melainkan dapat menggunakan metode lain dalam rangka mengaplikasikan komponen komunikasi sebagai salah satu komponen CLIL. (2) Buku suplemen teks negosiasi yang bermuatan kearifan lokal Timor dengan pendekatan CLIL dapat digunakan sebagai sumber belajar bagi peserta untuk mencapai tujuan pembelajaran. Peserta didik sebaiknya mendalami materi dari buku yang dikembangkan terlebih dahulu sebelum buku teks utama yang diadakan Kemendikbud karena dengan memiliki konsep dari hal yang kontekstual dapat membantu pemahaman terhadap kondisi global.

\section{DAFTAR PUSTAKA}

Coyle, D., 2008. CLIL-A pedagogical approach from the European perspective. In Encyclopedia of language and education. Springer, pp. 1200-1214.

Gagne, R.M. \& Briggs, L.J., 1974. Principles of instructional design., Holt, Rinehart \& Winston.

Kemendikbud, 2014. Bahasa Indonesia: Wahana Pengetahuan, Kementrian Pendidikan dan Kebudayaan.
Kemendikbud, 2015. Bahasa Indonesia.(Buku Siswa), Jakarta: Kementrian Pendidikan dan Kebudayaan.

Kemendikbud, 2016. Silabus Mata Pelajaran Sekolah Menengah Atas/Madrasah Aliyah/Sekolah Menengah Kejuruan/Madrasah Aliyah Kejuruan (SMA/MA/SMK/MAK), Jakarta: Kementrian Pendidikan dan Kebudayaan.

Mahsun, 2014. Teks dalam pembelajaran bahasa Indonesia kurikulum 2013, Jakarta: PT RajaGrafindo Persada.

Marsh, D. et al., 2012. European framework for CLIL teacher education.

Nieveen, N. et al., 1999. Design approaches and tools in education and training. Dordrecht: ICO Cluwer academic publisher.

Rothwell, W.J. \& Kazanas, H.C., 2011. Mastering the instructional design process: A systematic approach, John Wiley \& Sons.

Rusman, D. \& Pd, M., 2012. Model-Model Pembelajaran. Raja Grafindo, Jakarta.

Trianto, M.P., 2010. Mendesain Model Pembelajaran Inovatif-Progresif: Konsep, Landasan dan Implementasinya pada kurikulum Tingkat Satuan Pendidikan (KTSP). Jakarta: Kencana. 